\title{
EVALUASI PELAKSANAAN PROGRAM SMK KELAS JAUH DI MAN KARANGANYAR
}

\author{
Rudi Salam \\ SMK MAN Karanganyar Surakarta \\ rudi.salam99@yahoo.com \\ Soenarto \\ Fakultas Teknik Universitas Negeri Yogyakarta \\ soenarto@uny.ac.id
}

\begin{abstract}
Abstrak
Penelitian ini bertujuan untuk mengetahui penyelenggaraan program SMK Kelas Jauh di MAN Karanganyar.Penelitian ini merupakan jenis penelitian evaluasi dengan pendekatan model context, input, process dan product(CIPP)yang dikembangkan oleh Stuflebeam.Metode pengumpulan data yang digunakan adalah angket, wawancara, observasi dan dokumentasi. Data yang terkumpul dianalisis dengan teknik deskriptif kuantitatif menggunakan persentase.Hasil penelitian adalah sebagai berikut. (1) Hasil evaluasi context siswa termasuk cukup relevan (23,73), dan evaluasi context guru termasuk relevan $(41,14)$. (2) Hasil evaluasi input siswa menunjukkan skor rata-rata sebesar 43,41 (kategori baik) dan skor rata-rata evaluasi input guru adalah 67,83 (kategori baik). Kurikulum yang digunakan sama dengan kurikulum SMK induk ditambah bahasa Arab dan keterampilan las. (3) Hasil evaluasi process, baik dinilai oleh siswa dengan skor 94,71 maupun oleh guru dengan skor 70,86, termasuk kategori baik. (4) Hasil evaluasi product menurut siswa adalah 9,56 dan menurut guru 15,00 sehingga secara keseluruhan termasuk kategori cukup baik.
\end{abstract}

Kata kunci: evaluasi, kelas jauh, sekolah kejuruan

\section{THE EVALUATION OF THE IMPLEMENTATION OF THE DISTANCE CLASS PROGRAM OF VOCATIONAL SCHOOL IN MAN KARANGANYAR}

\begin{abstract}
This study aims to evaluate of the implementation of the Distance Class of Vocational School (SMK) in MAN Karanganyar.This study was evaluation research using the context, the inputs, the processes, and the products (CIPP) model developed by Stufflebeam.The data were collected using a questionnaire, interview, observation, and documentation and then analyzed using the percentage descriptive quantitative technique.The findings of research are as follows. (1) The result of the evaluation on the student context is relevant enough (23.73) and the teacher context is relevant. (2) The result of the input evaluation of the students with an average of score $43.41 \%$ is in a good category, and the score of the input evaluation of the teacher is in a poor category but the number of the teachers is sufficient with very suitable qualifications. The curriculum used is equal to the curriculum of the center school with two extras: Arabic subject and welding skill. (3) The results of the process evaluation, both students (94.71) and teachers (70.86) are in a good category. (4) The results of the product evaluation are 9.56 (based on the students) and 15.00 (based on the teachers), so that the overall results are in a good category.
\end{abstract}

Keywords: evaluation, distance class, vocational school 


\section{PENDAHULUAN}

Kualitas suatu bangsa dapat dilihat dari tingkat produktivitas, kualitas kerja dan budayanya. Produktivitas dan kualitas kerja berkaitan dengan faktor manusia (man), cara (method), peralatan (machine), bahan baku (material), dan biaya (money). Faktor yang paling berperan adalah manusia, apabila sumber daya manusia baik, faktor yang lain bisa diupayakan. Untuk menciptakan sumber daya manusia yang baik tidak terlepas dari lembaga yang mendidiknya.

Diungkapkan oleh Basuki (2005: 7) pendidikan bagi kehidupan manusia di era global seperti saat ini merupakan kebutuhan yang amat menentukan bagi masa depannya, tanpa melalui proses pendidikan yang baik, sulit kiranya bagi seseorang untuk menyesuaikan diri dengan perkembangan dan tuntutan zaman. Bahkan pendidikan tidak saja penting bagi kehidupan individual orang per orang, tetapi juga amat penting bagi tata kehidupan kolektif dalam rangka membangun fondasi jalan yang kokoh menuju terwujudnya masyarakat yang makmur, berkembang dan mandiri.

Disisi lain ada beberapa permasalahanpermasalahan pokok pendidikan yang harus diatasi. Setidaknya ada enam permasalahan pokok dalam sistem pendidikan nasional yang diungkapkan oleh Pusat Kurikulum Badan Penelitian dan Pengembangan Depdiknas yaitu: (1) menurunnya akhlak dan moral peserta didik; (2) kesempatan belajar tidak merata; (3) masih rendahnya efisiensi internal sistem pendidikan; (4) status kelembagaan; (5) manajemen pendidikan yang tidak sejalan dengan pembangunan nasional; dan (6) sumber daya manusia yang belum profesional.

Peraturan Pemerintah (PP) Nomor 29 Tahun 2005 merumuskan bahwa Pendidikan Menengah Kejuruan mengutamakan penyiapan siswa untuk memasuki lapangan kerja serta mengembangkan sikap profesional. Thomas Sukardi (2012:15) menyampaikan bahwa keberhasilan pendidikan kejuruan/SMK dapat diukur dari tingkat keterserapan para tamatan di dunia kerja. Jika tamatan mempunyai kemampuan seperti yang dituntut dunia kerja, maka dapat dikatakan lembaga pendidikan menengah kejuruan tempat tamatan tersebut belajar, betul-betul proses pembelajarannya mengarahkan dan mempersiapkan peserta didik memasuki dunia kerja. Untuk mencapai hal tersebut berbagai usaha dilakukan oleh SMK melalui peningkatan mutu pembelajaran. Mutu pembelajaran selalu ditingkatkan mengingat salah satu jenis sekolah yang memiliki materi pelajaran atau bidang studi relatif cepat berubah sesuai dengan permintaan lapangan kerja adalah sekolah kejuruan atau SMK.

Menurut Direktorat Pendidikan Menengah Kejuruan, tujuan dari pengembangan Program SMK Kecil Kelas Jauh pada Pondok Pesantren dan Institusi Penyelenggara Pendidikan lainnya adalah; (1) untuk memberikan kemudahan akses pendidikan menengah kejuruan pada daerah yang jauh jarak jangkauannya dari SMK yang sudah ada; (2) untuk mewadahi lonjakan lulusan SMP (spill-over) sebagai dampak keberhasilan program wajib belajar sembilan tahun; (3) untuk efisiensi dan pemberdayaan sumber daya yang tersedia pada pondok pesantren dan Institusi penyelenggara pendidikan lainnya.

SMK Kelas Jauh adalah SMK yang hanya menyelenggarakan satu jurusan yang sesuai dengan jurusan dengan SMK induk. Dalam pengelolaannya SMK Kelas Jauh menginduk pada SMK Negeri yang berada dalam satu Kabupaten/Kota. Sedangkan SMK induk adalah SMK Negeri yang memiliki nilai Akreditasi minimal B (baik) yang membantu SMK Kelas Jauh menyediakan guru produktif serta beberapa fasilitas pembelajaran baik teori maupun praktik.

Meskipun pengembangan SMK (perhatikan Gambar 1) penting untuk memenuhi kebutuhan tenaga kerja namun pengembangan SMK seharusnya memperhatikan prinsipprinsip yang pernah dirumuskan oleh Charles Prosser dalam Wardiman (1998: 38-39) bahwa pendidikan kejuruan akan efisien dan efektif antara lain jika: (1) lingkungan dimana siswa dilatih merupakan replika lingkungan dimana ia akan bekerja. (2) tugas-tugas yang diberikan kepada siswa dilakukan dengan cara, alat dan mesin yang sama yang ditetapkan ditempat kerja. (3) diajar oleh guru dan instruktur yang telah memiliki pengalaman dan berhasil di dalam menerapkan keterampilan dan pengetahuan mengenai operasi dan proses kerja yang dilakukan. (4) dapat menumbuhkan kebiasaan kerja yang efektif kepada siswa. Hal tersebut hanya akan terjadi apabila training yang diberikan berupa pekerjaan nyata. (5) pelatihan diberikan hanya 
diberikan kepada seseorang yang memerlukannya, yang menginginkannya dan yang dapat untung darinya. (6) pembiayaan pendidikan disediakan paling tidak biaya minimum proses keseluruhan pembelajaran, jika tidak terpenuhi maka pendidikan kejuruan tidak boleh dipaksakan beroperasi.

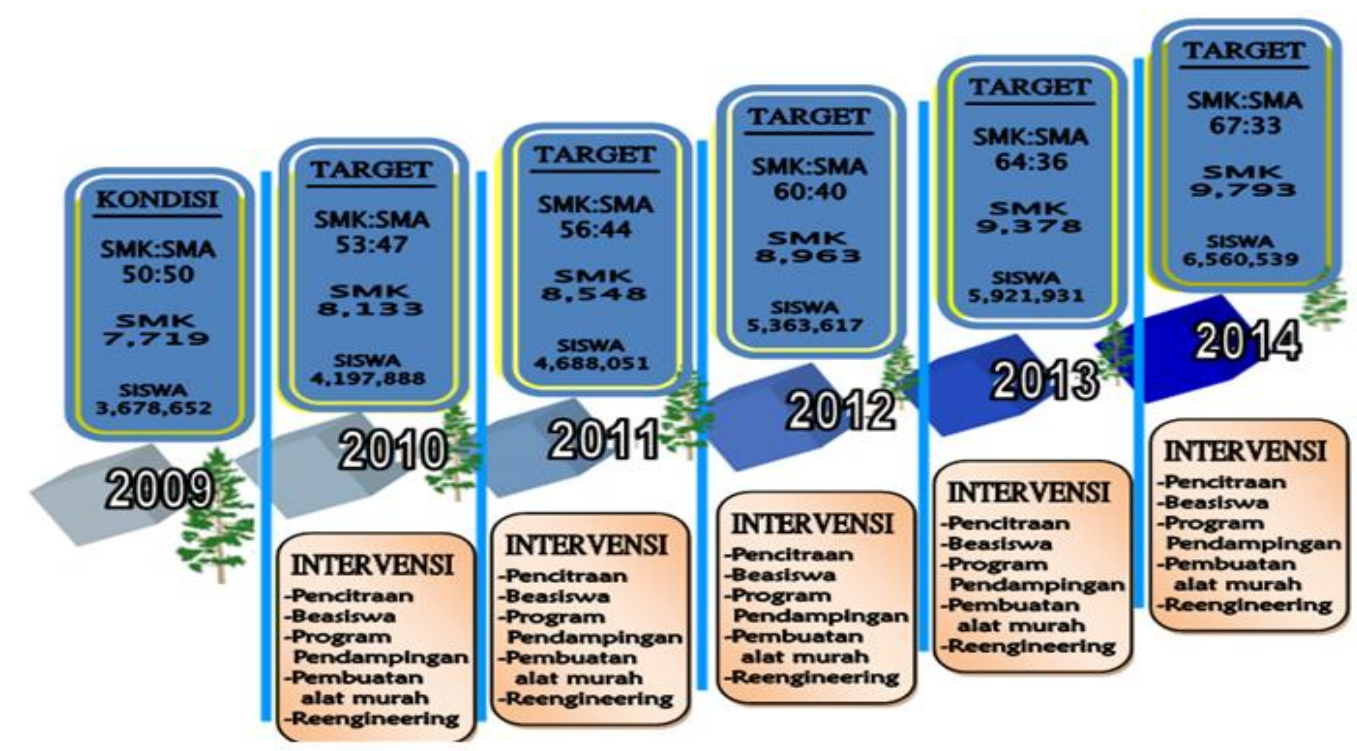

Gambar 1. Road Map Pengembangan SMK

Tahun 2010-2014 9doni., dkk, 2010:8)

Soenarto (2003: 26) menyatakan jika pendidikan kejuruan tidak menyiapkan peserta didik dengan sebaik-baiknya, lulusan pendidikan kejuruan akan menjadi asing di negara sendiri sementara tenaga kerja asing bekerja mendapatkan uang dari Negara Indonesia yang sekarang dalam kategori miskin. Slamet PH (2005: 45-46) juga menambahkan bahwa idealisasi pendidikan kejuruan sangat jelas yaitu pendidikan kejuruan akan efektif apabila dimulai dari dan diakhiri di Dunia Usaha/Dunia Industri (DU/DI).

Laporan ketenagakerjaan di Indonesia (2010: 160) menyatakan bahwa SMK masih berperan penting mendidik pekerja masa depan, namun diperlukan perbaikan mutu dan relevansi keahlian. Siswa SMK dipersiapkan dengan berbagai keterampilan kejuruan sesuai bidang yang dipelajarinya.

Pendidikan Kejuruan didasarkan pada prinsip meniru dalam arti proses belajar berlangsung melalui peragaan dan peniruan, berlanjut dari aktivitas membantu berbuat sampai pada berbuat sendiri (Helmut Nolker \& Eberhad, 1983: 108). Dengan bekal inilah siswa yang sudah lulus dapat menerapkan keteram- pilannya. Kemampuan siswa dalam praktik akan semakin meningkat jika sarana praktik memadai dalam hal kuantitas dan kualitasnya. SMK Kelas Jauh cenderung belum mempunyai sarana praktik yang mencukupi sehingga berpengaruh pada keterampilan siswa.

Dalam hal kompetensi guru, guru hendaknya menguasai kompetensi dan metode pembelajaran sesuai dengan karakteristik peserta didik dan karakteristik materi yang diajarkan. Dalam makalahnya, Sentot Wijanarka (25 Juli 2009) mengungkapkanbahwa hal yang sangat penting dirasakan dalam dunia pendidikan dalam penerapan ICT atau Information and Comunication Technologies adalah dalam pengembangan materi ajar dan strategi pembelajaran. Guru dan siswa pada saat ini tidak bisa hanya mengandalkan materi ajar buku cetak karena proses pembaruan (revisi atau updatenya) memerlukan waktu yang relatif lama, tetapi harus dilengkapi juga dengan e-book atau buku digital. Guru tidak hanya membatasi komunikasi dengan siswanya dengan tatap muka di kelas, tetapi juga bisa mengirimkan tugas, materiajar, nilai, dan 
diskusi menggunakan ICT baik melalui email, e-learning, sms, maupun blog.

SMK Kelas Jauh di Madrasah Aliyah Negeri (MAN) Karanganyar merupakan tindak lanjut dalam rangka merespon Surat Direktur Pendidikan Menengah dan Kejuruan Jakarta Nomor 1656/C5.2/MN/2003, tentang Pengembangan SMK Kelas Jauh di Ponpes/ Instansi lain dan pembukaan SMK Kecil, tertanggal 03 September 2003. Program penyelenggaraan SMK Kelas Jauh di MAN Karanganyar dimulai pada tahun diklat 2004/2005 MAN Karanganyar yang saat itu mengadakan MoU (Memorandom of Understanding) dengan SMKN 2 Karanganyar.

Penyelenggaraan pendidikan kejuruan idealnya dilakukan oleh orang-orang yang kompeten di bidang kejuruan. Namun sumber daya yang dimiliki MAN Karanganyar sebagian besar adalah guru yang kurang berkompetensi di bidang kejuruan. Pendidik dalam hal ini guru sebagian besar kurang memahami keSMK-an. Beberapa guru kurang kompeten di bidang keahlian teknik mesin meskipun pernah mengajar program keterampilan yang diselenggarakan oleh MAN yaitu: keterampilan las, mebelair, otomotif, dan tata busana. Dalam aspek lain, peralatan maupun mesin untuk kegiatan praktik terbatas jumlah maupun kualitasnya. Kegiatan praktik mesin CNC (Computer Numericaly Control) masih menginduk ke SMKN 2 Karanganyar yang berjarak kurang lebih 3 kilometer dari lokasi. Hal ini kadang menjadi hambatan tersendiri karena beberapa anak sering membolos pelajaran ini dengan berbagai macam alasan.

Sarana prasarana olah raga juga kurang memadai sehingga untuk mata pelajaran pendidikan jasmani dan olah raga sering diadakan di lapangan luar sekolah yang jaraknya sekitar 2 kilometer.Hal ini juga berdampak pada menurunnya ketertiban dan kedisiplinan siswa. Dalam hal manajemen organisasi, struktur organisasi SMK Kelas Jauh ini masih lebur dengan struktur organisasi MAN Karanganyar, sehingga tugas kurang fokus, dan ada kesan tumpang tindih dan penumpukan tugas dan wewenang oleh beberapa pengelola. Hal ini mengakibatkan pengelolaan SMK Kelas Jauh ini kurang maksimal.

Bagi guru MAN yang tidak secara langsung aktif dalam mengelola SMK Kelas Jauh ini kurang semangat dalam mendukung keberadaannya.Hal ini dikarenakan kurangnya rasa handarbeni dan partisipasi dalam perhatian, pemikiran, maupun pelaksanaannya dari guru maupun karyawan MAN Karanganyar, karena menganggap SMK Kelas Jauh ini sebagai tugas tambahan saja.

Akibatnya kegiatan-kegiatan yang dilaksanakan kurang mendapat dukungan dari para guru yang lain.

Suatu program yang tidak mempunyai kejelasan tujuan akan berpengaruh terhadap hasil dari pelaksanaan program tersebut. Tujuan program dapat diumpamakan sebuah peta yang dapat menunjukkan arah perjalanan.

Pentingnya penelitian evaluasi program pembelajaran SMK Kelas Jauh di MAN Karanganyar pada berbagai aspek pendidikan secara menyeluruh akan bermanfaat sebagai informasi perkembangan Program Kelas Jauh terkait kualitas dan mutu lulusannya. Hasil evaluasi ini diharapkan dapat dijadikan masukan bagi pemerintah Kabupaten Karanganyar yang baru saja mendeklarasikan Kabupaten Karanganyar sebagai Kota Vokasi.

Berbagai persoalan pada Program SMK Kelas Jauh antara lain: (1) adanya keluhankeluhan dari pengelola mengenai kurang relevannya program SMK Kelas Jauh dengan kesiapan para pendidik/guru di Madrasah Aliyah. (2) fasilitas/peralatan praktik (sarana olah raga) untuk siswa kurang memadai baik dari segi jumlah dan kualitasnya. (3) bahan ajar, referensi, dan media pembelajaran kurang mencukupi. (4) tenaga pengajar di bidang teknik masih terbatas dari segi kuantitas maupun kualitasnya. (5) beberapa buku teks pelajaran sudah ada, namun perpustakaan belum lengkap. (6) dukungan masyarakat (orang tua siswa) rendah dalam hal pendanaan. (7) manajemen sekolah masih menginduk ke dua sekolah. (8) tidak adanya kepastian kelanjutan status SMK (apakah tetap menginduk, mandiri menjadi sekolah negeri, mandiri menjadi swasta, atau bahkan penutupan program kelas jauh. (9) elama delapan tahun berdirinya SMK Kelas Jauh ini belum ada yang mengevaluasi sejauh mana keterlaksanaan program tersebut.

Penelitian ini memiliki tujuan sebagai berikut: (1) untuk mengetahui kondisi context pelaksanaan program penyelenggaraan SMK Kelas Jauh di MAN Karanganyar yang ditinjau dari kepedulian masyarakat, relevansi program, dan regulasi pemerintah. (2) untuk mengetahui input yang meliputi karakteristik 
guru dan siswa, kurikulum, sarana prasarana dan sarana pendukung untuk pelaksanaan program kelas jauh. (3) untuk mengetahui process pembelajaran baik teori maupun praktik, penilaian hasil pembelajaran, serta kerja sama dengan institusi lain. (4) untuk mengetahui hasil belajar, keterserapan lulusan, dan tanggapan masyarakat terhadap lulusan.

Penelitian ini diharapkan dapat memberikan sumbangsih positif baik secara praktis maupun teoritis bagi: (1) Dinas Pendidikan Kabupaten, sebagai informasi dan masukan untuk mengambil kebijakan. (2) kepala sekolah dan Guru, dapat dijadikan informasi dan masukan untuk pengambilan keputusan sekolah mengenai kelanjutan program kelas jauh ini dengan beberapa alternatif pilihan yaitu; (a) akan tetap menginduk ke SMKN $2 \mathrm{Ka}$ ranganyar; (b) mandiri sebagai sekolah negeri; (c) mandiri sebagai sekolah swasta; (d) penutupan Program SMK Kelas Jauh. (3) orang tua, dapat dijadikan informasi mengenai mutu dan kualitas sekolah.

Sekolah sebagai lembaga pendidikan harus dikelola semaksimal mungkin. Sugiyono (2003: 21-24) menyatakan bahwa manajemen pendidikan kejuruan yang profesional adalah manajemen yang cerdas yaitu manajemen yang mampu melaksanakan fungsifungsi manajemen secara sungguh-sungguh, konsisten dan berkelanjutan dalam mengelola sumber daya sehingga tujuan pendidikan kejuruan dapat dicapai secara efektif dan efisien. Menurut Udin Syaefudin (2010: 155), sarana merupakan fasilitas yang mempengaruhi secara langsung terhadap keberhasilan siswa dalam kegiatan mencapai tujuan pembelajaran.

Di dalam Kamus Oxford Advanced Learner's Dictionary of Current English, evaluation atau evaluasi bermakna to find out, decide the amount or value yang artinya suatu upaya untuk menentukan nilai atau jumlah. Tyler (1949: 105), mendifinisikan pengertian evaluasi: "evaluation as the process of determining to what extent the educational objectives are being realized... ". evaluasi merupakan proses yang menentukan sampai sejauh mana tujuan pendidikan dapat dicapai.

Lebih lanjut Stufflebeam dalam (Worthen \& Sanders, 1973:129) menyatakan, "evaluation is the process of delineating, obtaining and providing useful information for judging decision alternative”. Maksudnya adalah evaluasi sebagai proses yang menggambarkan, menghasilkan dan menyajikan informasi yang berguna untuk pengambilan keputusan.

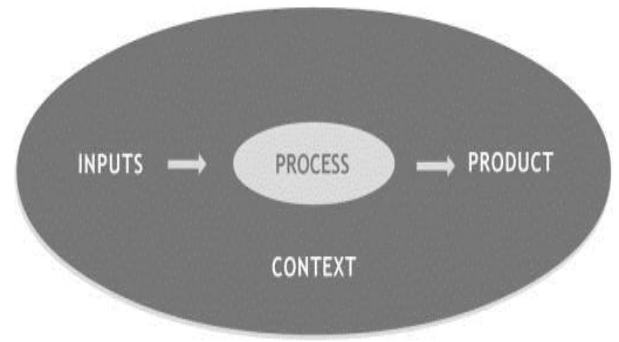

Gambar 2. The CIPP Model of Evaluation

(Sumber: http://www.cglrc.cgiar.org)

Menurut Stufflebeam L.D. \& Shinkfield, A.J. (1985: 156), this basic framework of the CIPP was complete (context evaluation to help develop goals, input evaluation to help shape proposal, process evaluation to guide implementation, and product evaluation to serve recycling decisions. Model ini memiliki kerangka dasar yang lengkap yaitu evaluasi konteks untuk membantu merumuskan tujuan, evaluasi input membantu dalam menyusun program, evaluasi proses untuk mengarahkan keterlaksanaan suatu program dan evaluasi produk untuk mengetahui ketercapaian suatu program.

Banerjee dan Muley yang dikutip Ajit (2011: 61), menyatakan bahwa tiga tahapan dalam aktifitas pendidikan teknik yang saling berkaitan yaitu: (1) input adalah kebutuhan masyarakat dan sumber daya, (2) process yaitu mengenai pembelajaran, dan (3) output yaitu kemampuan tenaga kerja.

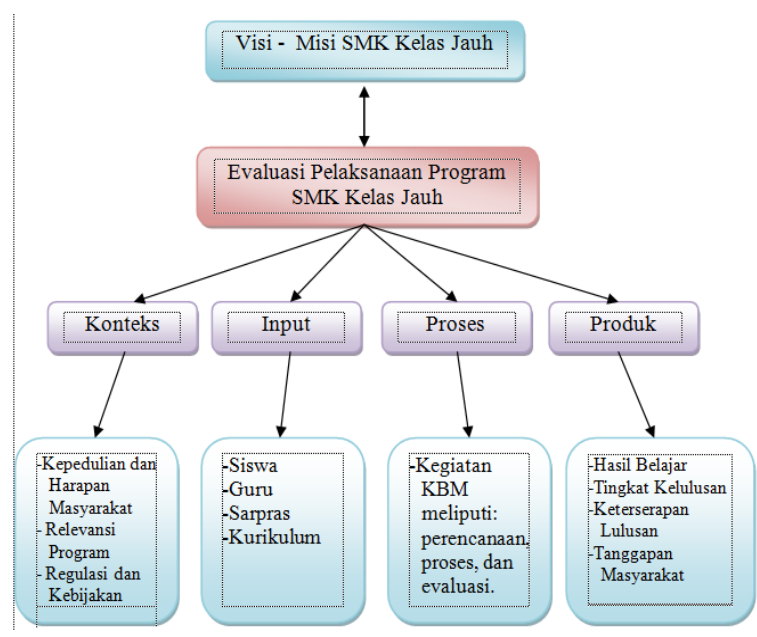

Gambar 3. Alur Pelaksanaan Evaluasi 


\section{METODE PENELITIAN}

Penelitian ini adalah penelitian evaluasi yang bertujuan untuk mengevaluasi program SMK Kelas Jauh di MAN Karanganyar.Model evaluasi yang digunakan adalah Context, Input, Process, Product(CIPP) yang dikembangkan oleh Stuffelbeam dan Shinkfield tahun 1985.Maksud diadakannya evaluasi adalah mengumpulkan data atau informasi untuk dibandingkan dengan kriteria yang telah dibuat kemudian diambil kesimpulan. Kesenjangan antara kondisi nyata dengan harapan itulah yang dicari. Dari kesenjangan tersebut diperoleh gambaran apakah pelaksanaan program yang diteliti sudah sesuai, kurang sesuai, atau tidak sesuai dengan kriteria yang telah ditetapkan.

Pendekatan yang digunakan adalah kuantitatif deskriptif yang didukung dengan pendekatan kualitatif. Proses pengambilan keputusan dilakukan dengan membandingkan temuan/fakta yang terdapat pada konteks, input, proses dan produk dengan standar atau kriteria yang telah ditetapkan sebelumnya.

Penelitiandilaksanakan di SMK Kelas Jauh di MAN Karanganyar yang hanya mempunyai satu kompetensi keahlian yaitu Teknik Pemesinan.Waktu pelaksanaan penelitian dimulai bulan November 2012 sampai dengan bulan April 2013.

Subjek dalam penelitian ini adalah program SMK Kelas Jauh di MAN Karanganyar. Sumber informasi yang digali yaitu Guru, dan Siswa Kelas XII (dua belas).

Teknik pengumpulan data yang digunakan dalam penelitian ini adalah: (1) pengamatan (observasi), (2) wawancara (interview), (3) dokumentasi, (4) kuesioner.

Data yang diperoleh akan dianalisis secara deskriptif persentase. Selanjutnya adalah membandingkan data dengan standar atau kriteria yang ada. Selanjutnya dicari harga rerata (M), Standar Deviasi (SD), Modus (Mo) dan Median (Me) dari setiap ubahan penelitian melalui bantuan program SPSS 16.0for windows. Kemudian semua hasil perhitungan tersebut ditafsirkan dan data dianalisis secara objektif sesuai dengan masalah penelitian. Pedoman pengkategorian skor sebagai berikut.
Tabel 1. Kriteria Skor Rata-Rata per Item Soal

\begin{tabular}{cc}
\hline Skor Rata-Rata $(\mathrm{X})$ & Kriteria \\
\hline $\mathrm{X} \geq 4$ & Sangat Baik \\
$3,33 \leq \mathrm{X}<4$ & Baik \\
$2,67 \leq \mathrm{X}<3,33$ & Cukup Baik \\
$2 \leq \mathrm{X}<2,67$ & Kurang Baik \\
$\mathrm{X}<2$ & Tidak Baik \\
\hline
\end{tabular}

\section{HASIL PENELITIAN DAN PEMBAHASAN}

\section{Evaluasi Konteks}

\section{Kepedulian dan Harapan Masyarakat}

1. Perhatian Pemda dan Masyarakat

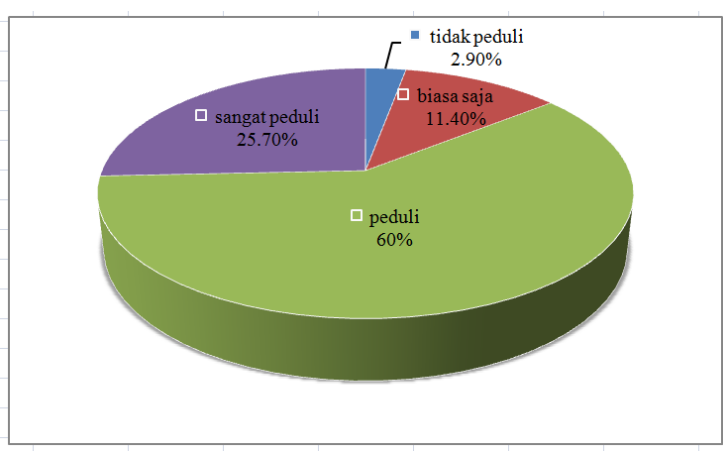

Gambar 4. Diagram Kepedulian Pemerintah Daerah terhadap KeberadaanSMK Kelas Jauh Berdasarkan Penilaian

Guru

Berdasarkan gambar $4 \mathrm{di}$ atas menunjukkan bahwa dari 35 orang guru ada 9 atau $(25,7 \%)$ menyatakan bahwa Pemda sangat peduli terhadap keberadaan SMK Kelas Jauh di MAN Karanganyar, 21 orang atau (60\%) menyatakan bahwa Pemda peduli, 4 orang atau $(11,40 \%)$ menyatakan kepedulian Pemda biasa saja dan hanya 1 orang atau $(2,90 \%)$ menyatakan bahwa Pemda tidak peduli. Dengan rata-rata skor 4,09 maka kepedulian Pemda terhadap keberadaan SMK Kelas Jauh termasuk dalam kategori sangat baik.

Menurut pengelola SMK Kelas Jauh di MAN Karanganyar kepedulian Pemda dibuktikan dengan beberapa hal diantaranya yaitu: (1) dikeluarkkannya surat ijin pendirian SMK Kelas Jauh, (2) adanya kunjungan Bupati Karanganyar pada tahun 2006 saat awal-awal 
sekolah ini berdiri, (3) diijinkannya sampai tahun ini untuk tetap melakukan kegiatan pembelajaran dengan MoU dengan SMKN 2 Karanganyar, serta (4) adanya fasilitasi bantuan pembiayaan dari Pemda setempat.

2. Harapan Masyarakat terhadap Keberadaan SMK Kelas Jauh

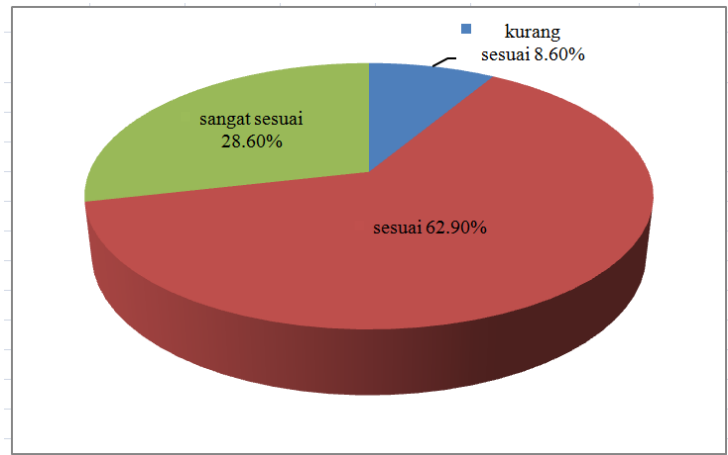

Gambar 5. Kesesuaian Keberadaan SMK Kelas Jauh dengan Harapan Masyarakat Berdasarkan Penilaian Guru

Berdasarkan data yang diperoleh menunjukkan bahwa 10 orang atau $(28,60 \%)$ menyatakan sangat sesuai, 22 orang atau $(62,90 \%)$ menyatakan sesuai, dan hanya 3 orang atau $(8,60 \%)$ menyatakan bahwa keberadaan SMK Kelas Jauh ini kurang sesuai dengan harapan masyarakat. Dengan rata-rata skor 4,20 maka dapat disimpulkan bahwa keberadaan SMK Kelas Jauh sangat sesuai dengan harapan masyarakat.

\section{Relevansi Program}

1. Kesesuaian program dengan kebutuhan warga masyarakat

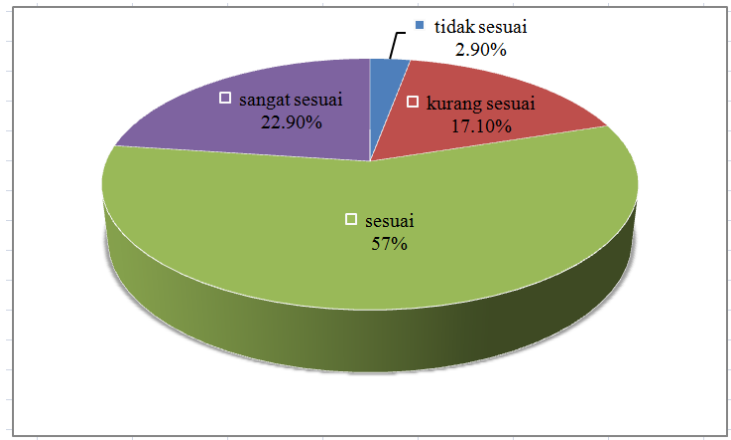

Gambar 6. Kesesuaian Program SMK Kelas Jauh dengan Kebutuhan Siswa

Berdasarkan gambar 6 di atas ada 16 orang atau $(22,90 \%)$ menyatakan sangat sesuai, 40 orang atau $(57,10 \%)$ sesuai, 12 orang atau $(17,10 \%)$ kurang sesuai, dan hanya 2 orang atau $(2,90 \%)$ menyatakan tidak sesuai. Dengan skor rata-rata 4 maka penyelenggaraan program SMK Kelas Jauh sesuai dengan kebutuhan siswa.

2. Kesesuaian program SMK Kelas Jauh dengan kondisi ekonomi masyarakat

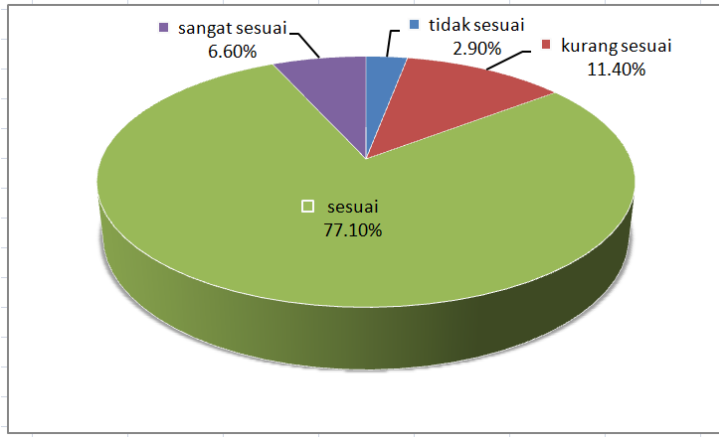

Gambar 7. Kesesuaian Program SMK Kelas Jauh dengan Kondisi Ekonomi Masyarakat Berdasarkan Penilaian Guru

Berdasarkan gambar 7 ada 3 orang atau $(6,60 \%)$ menyatakan bahwa penyelenggaraan program SMK Kelas Jauh sangat sesuai dengan kondisi ekonomi masyarakat, 27 orang atau $(77,10 \%)$ sesuai, 4 orang atau $(11,40 \%)$ kurang sesuai, dan hanya 1 orang atau $(2,90 \%)$ menyatakan tidak sesuai. Dengan skor rata-rata 3,91 maka kesesuaian program dengan kondisi ekonomi masyarakat termasuk kategori sesuai.

3. Kesesuaian Program SMK Kelas Jauh dengan Potensi Sekolah

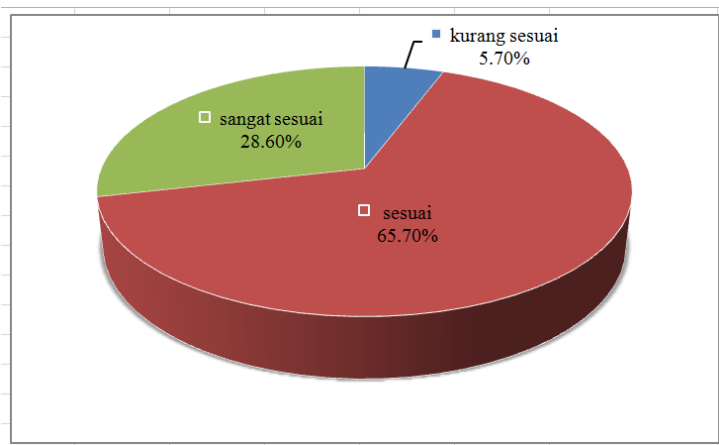

Gambar 8. Kesesuaian Program SMK Kelas Jauh dengan Potensi Sekolah Berdasarkan Penilaian Guru

Data pada gambar 8 menunjukkan bahwa 10 orang atau $(28,60 \%)$ dari 35 guru menyatakan sangat sesuai, 23 orang atau $(65,70 \%)$ sesuai, dan hanya 2 orang atau 
$(5,70 \%)$ menyatakan kurang sesuai. Dengan rata-rata skor 4,23 maka dapat disimpulkan bahwa penyelenggaraan SMK Kelas Jauh sangat sesuai dengan potensi sekolah.

4. Akses terhadap SMK Kelas Jauh

Kemudahan menjangkau menurut penilaian guru dan siswa terlihat pada Gambar 9 di bawah ini.

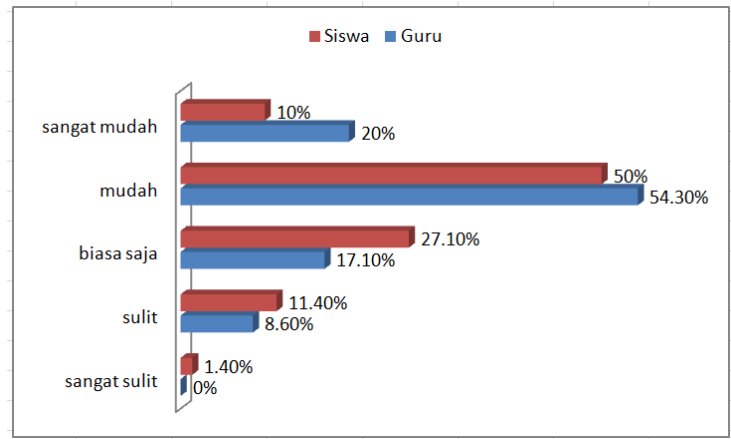

Gambar 9. Kemudahan Menjangkau SMK Kelas Jauh

Berdasarkan gambar di atas diperoleh rata-rata skor siswa 3,56 dan 3,86 untuk ratarata skor guru maka dapat disimpulkan bahwa SMK Kelas Jauh mudah dijangkau dengan rata-rata skor akhir 3,71.

\section{Regulasi dan Kebijakan Pemerintah}

SMK Kelas Jauh merupakan program resmi dari pemerintah pusat sehingga penyelenggaraannya didukung dengan berbagai hal diantaranya. (1) Surat Direktur Pendidikan Menengah dan Kejuruan Jakarta No. 1656/C5.2/MN/2003, tentang Pengembangan SMK Kelas Jauh di Ponpes/Instansi lain, tertanggal 03 September 2003. (2) Surat Ijin Bupati Karanganyar No. 420/6295.5 tentang Penambahan Program SMK Terpadu (SMK Kecil) Madrasah Aliyah Negeri Karanganyar. (3) Kepala Seksi SMK Dinas Pendidikan dan Kebudayaan Provinsi Jateng yaitu Drs. Kartono, M.Pd, pada tanggal 08 April 2008 menyatakan bahwa persentase jumlah siswa SMK dibandingkan dengan siswa SMA di Jateng sudah lebih banyak. Siswa SMK 52,7\%, siswa SMA 47,3\%. Jadi, sudah layak disebut provinsi vokasi. Beberapa daerah sudah menunjukkan kenaikan jumlah siswa SMK. Misalnya Kota Solo yang lebih dahulu dicanangkan sebagai kota vokasi. Begitu pula Kabupaten Karanganyar yang persentasenya mencapai 55\%:45\% untuk siswa SMK. Dengan pencanangan provinsi vokasi itu maka Pemerintah provinsi akan mencurahkan lebih banyak pemikiran dan anggaran untuk mengembangkan SMK. Pada tahun 2008, anggaran khusus pengembangan SMK mencapai Rp 52,8 miliar, meningkat hampir $300 \%$ dibandingkan dengan tahun 2007. Artinya, Pemerintah provinsi memang tidak main-main. Sebab, SMK harus semakin dimajukan, sehingga yang dididik adalah generasi siap kerja di kelas menengah, kelas teknisi. (http://www.suaramerdeka.com).(4) Pendeklarasian Kabupaten Karanganyar sebagai Kabupaten Vokasi pada tanggal $02 \mathrm{Mei}$ 2013 oleh Wakil Bupati Karanganyar dalam rangka Peringatan Hari Pendidikan Nasional. Hal ini sebagai tindak lanjut kebijakan Provinsi Jawa Tengah yang telah mendeklarasikan diri sebagai Provinsi Vokasi. Oleh karena itu Pemda berusaha menyiapkan berbagai sarana dan prasarana penunjang Kabupaten Vokasi (Solopos, 03 Mei 2013).

Dengan berbagai hal di atas maka penyelenggaraan SMK baik itu negeri maupun swasta di Kabupaten Karanganyar sangat didukung keberadaannya.

\section{Evaluasi Input}

\section{Karakteristik Guru}

\section{Motivasi Kerja}

Berdasarkan Gambar 10 ada 8 orang atau $(22,90 \%)$ sangat tidak setuju, 13 orang atau $(37,10 \%)$ tidak setuju, 11 orang atau $(31,40 \%)$ kurang setuju, dan 3 orang atau $(8,60 \%)$ setuju. Dengan skor rata-rata 2,26 termasuk dalam kategori kurang baik.

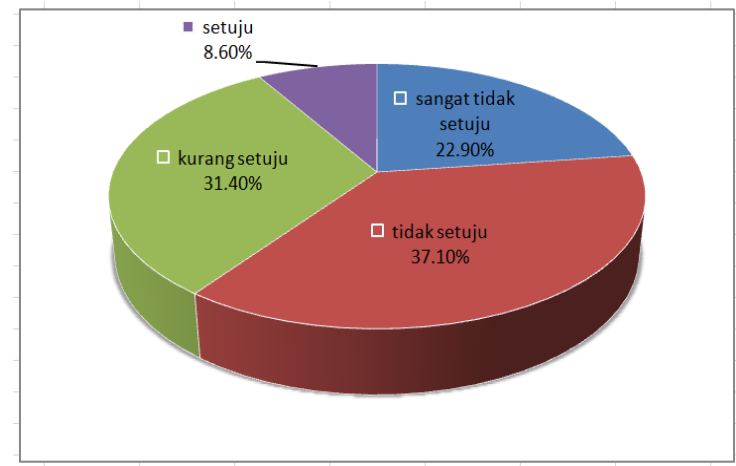

Gambar 10. Persentase Guru Melaksanakan Tugas Hanya Jika Diberi Penghargaan Kepala Sekolah 


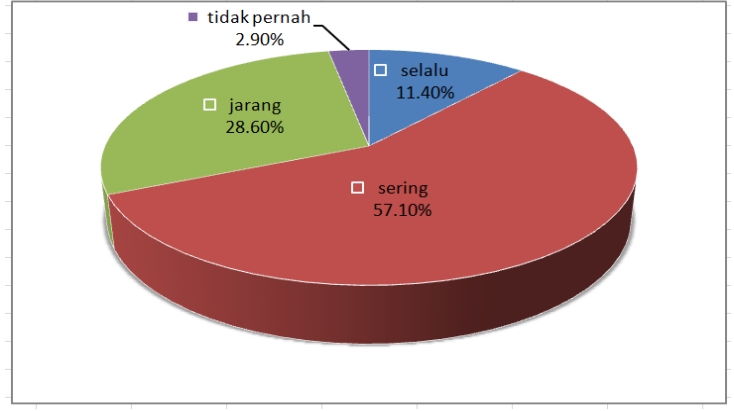

Gambar 11. Persentase Guru yang Mengembangkan Media Pembelajaran Sendiri

Data yang diperoleh ada 4 orang atau $(11,40 \%)$ selalu mengembangkan media pembelajaran sendiri, 20 orang atau $(57,10 \%)$ sering, 10 orang atau $(28,60 \%)$ jarang, dan 1 orang atau $(2,90 \%)$ tidak pernah. Dengan ratarata skor 3,77 termasuk dalam kategori baik.

\section{Kuantitas Guru di SMK Kelas Jauh}

Berdasarkan wawancara dengan pengelola bahwa jumlah guru di SMK Kelas Jauh termasuk sudah mencukupi sesuai dengan jumlah mata pelajaran dan rombongan kelas yang ada. Jumlah total guru adalah 35 orang. Guru Normatif sebanyak 10 orang. Guru Adaptif sebanyak 11 orang dan Guru Produktif sebanyak 14 orang. Guru Normatif dan Adaptif $100 \%$ dari MAN Karanganyar sedangkan guru Produktif 75\% dari SMKN 2 Karanganyar sedangkan sisanya yaitu $25 \%$ dari MAN Karanganyar.

3. Kualifikasi

Dari 35 guru terdapat 6 guru $(17,14 \%)$ guru berpendidikan S2 dan 29 guru $(82,86 \%)$ berpendidikan S1. Sejumlah 33 orang atau $(94,29 \%)$ guru mengajar sesuai dengan latar belakang pendidikan dan hanya 2 orang atau $(5,71 \%)$ mengajar tidak sesuai dengan latar pendidikan.

\section{Kompetensi}

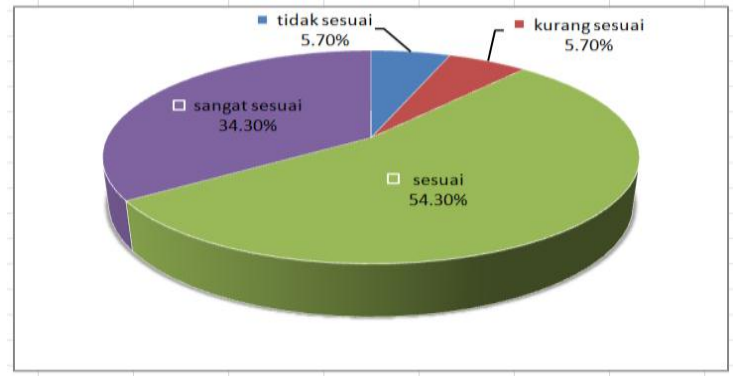

Gambar 12. Kesesuaian Pelatihan dengan Latar Belakang Pendidikan
Berdasarkan data ada 12 orang atau $(34,30 \%)$ termasuk kategori sangat sesuai, 19 orang atau $(54,30 \%)$ sesuai, 2 orang atau $(5,70 \%)$ kurang sesuai, dan 2 orang atau $(5,70 \%)$ termasuk kategori tidak sesuai. Dengan rata-rata skor 4,17 termasuk kategori sangat sesuai. Ditinjau dari pengalaman kerja terdapat $34(97,14 \%)$ dari 35 guru yang telah bekerja di atas 3 tahun dan hanya 1 orang $(2,86 \%)$ yang bekerja di bawah 3 tahun.

\section{Karakteristik Siswa}

\section{Motivasi Belajar}

Salah satu indikator motivasi belajar adalah kedisiplinan masuk kelas. Persentase siswa masuk kelas tepat waktu dapat dilihat pada Gambar 13.

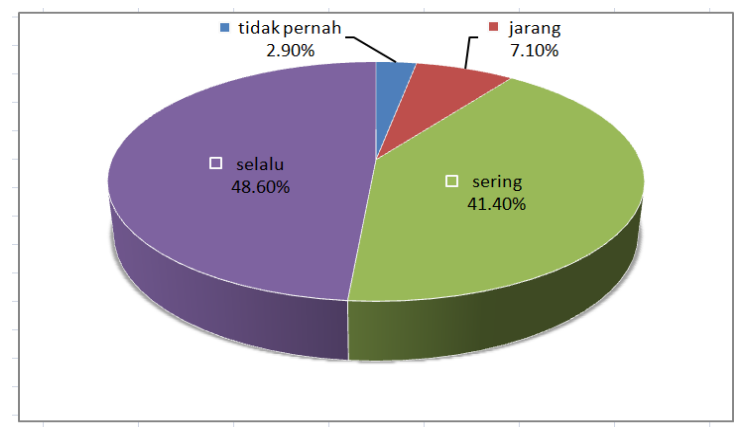

Gambar 13. Persentase Siswa Masuk Kelas Tepat Waktu

Berdasarkan data penelitian terdapat 34 orang atau $(48,60 \%)$ selalu masuk tepat waktu, 29 orang atau $(41,40 \%)$ sering masuk tepat waktu, 5 orang atau $(7,10 \%)$ jarang masuk tepat waktu, dan 2 orang atau $(2,90 \%)$ tidak pernah masuk kelas tepat waktu. Dengan rata-rata skor 4,33 termasuk kategori sangat baik.

2. Pendidikan

Latar belakang pendidikan siswa sebelum masuk SMK Kelas Jauh terlihat seperti Gambar 14 di bawah ini.

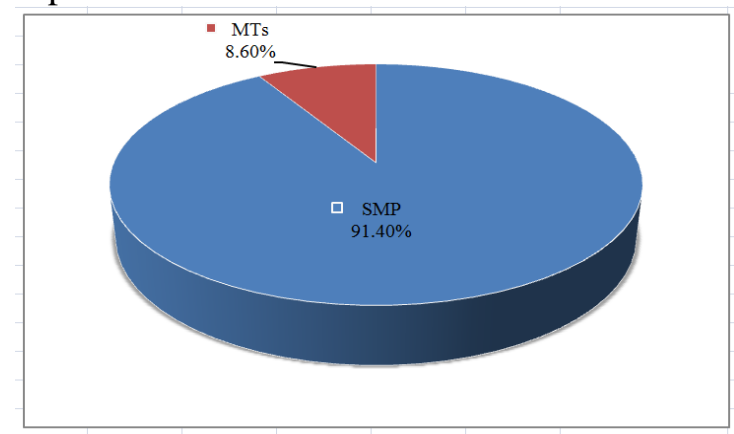

Gambar 14. Latar Belakang Pendidikan Siswa 
Meskipun SMK Kelas Jauh di MAN Karanganyar bernuansa keagamaan namun latar belakang siswa ternyata di dominasi oleh sekolah umum yaitu $(91,40 \%)$ dari Sekolah Menengah Pertama dan hanya $(8,60 \%)$ dari Madrasah Tsanawiyah.

\section{SES (Sosio Economic Status)}

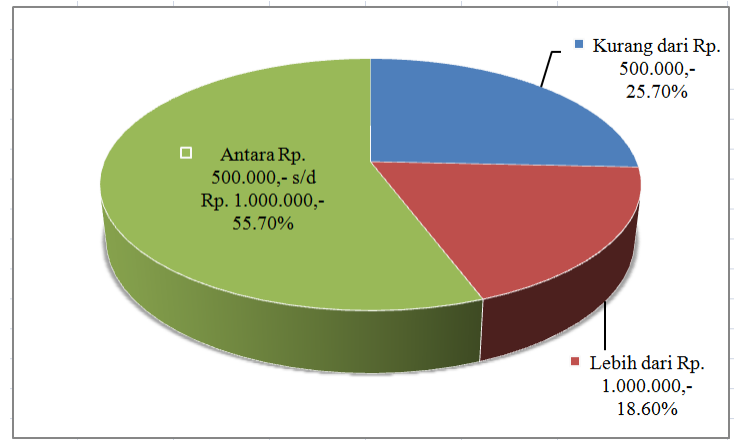

Gambar 15. Penghasilan Orang Tua Siswa

Dari Gambar 15 menunjukkan bahwa $(25,70 \%)$ orang tua siswa berpenghasilan kurang dari Rp. 500.000,-, $(55,70 \%)$ berpenghasilan antara Rp. 500.000,- s/d. Rp. 1.000.000,- dan $(18,60 \%)$ berpenghasilan lebih dari Rp. 1.000.000,-. Hal ini menunjukkan bahwa tingkat ekonomi orang tua siswa rata-rata termasuk kategori menengah ke bawah.

Pekerjaan orang tua siswa ditunjukkan pada gambar di bawah 16 ini.

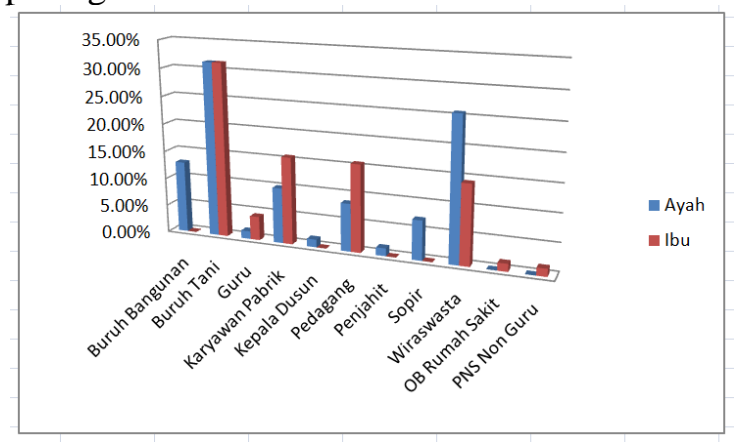

Gambar 16. Pekerjaan Orang Tua Siswa

Berdasarkan pada Gambar 16 di atas terlihat bahwa sebagian besar pekerjaan orang tua adalah sebagai buruh, wiraswasta, karyawan pabrik, dan pedagang.

\section{Kurikulum}

Kurikulum yang digunakan adalah Kurikulum Tingkat Satuan Pendidikan. Susunan program SMK Kelas Jauh di MAN Karanganyar meliputi normatif, adaptif, dan produktif. Masa pendidikan ditempuh selama 3 (tiga)
tahun.SMK Kelas Jauh di MAN Karanganyar menambahkan kompetensi Bahasa Arab untuk program adaptif dan Keterampilan Las untuk program produktif, dimana hal ini tidak ada pada SMK Induk. Ciri khas yang lain yang kental adalah adanya budaya tilawah (membaca Al-qur'an) tiap pagi hari sebelum pelajaran dimulai. Untuk pembelajaran prak-tik CNC berada di sekolah induk yaitu di SMKN 2 Karanganyar

\section{Karakteristik Sarana dan Prasarana}

1. Gedung dan Ruang Pembelajaran

Data hasil penelitian menunjukkan bahwa berdasarkan penilaian peserta didik kondisi gedung dan ruang pembelajaran di SMK Kelas Jauh termasuk dalam kategori cukup memadai. Sedangkan hasil penilaian yang dilakukan guru sendiri menunjukkan bahwa kondisi gedung dan ruang pembelajaran di SMK Kelas Jauh termasuk dalam kategori memadai. Sehingga dapat diambil kesimpulan bahwa dari kedua penilaian tersebut kondisi gedung dan ruang pembelajaran di SMK Kelas Jauh termasuk dalam kategori cukup memadai. Sedangkan ruang kantor guru berdasarkan penilaian guru diperoleh skor rata-rata 3,54 termasuk kategori baik atau memadai.

\section{Referensi untuk belajar di perpustakaan}

Berdasarkan hasil angket diketahui bahwa kondisi perpustakaan dan perlengkapan ruangan yang dimiliki dalam keadaan kurang memadai. Ketersediaan buku referensi penunjang belajar bagi siswa termasuk kategori cukup memadai.

\section{Evaluasi Proses}

\section{Persiapan Pembelajaran}

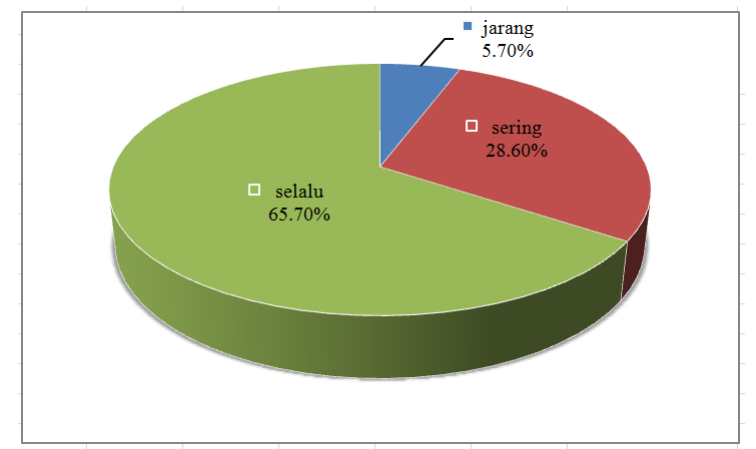

Gambar 17. Persentase Guru yang Membuat Persiapan Sebelum KBM 
Berdasarkan Gambar 17 tersebut terdapat 23 orang atau $(65,70 \%)$ guru selalu membuat persiapan sebelum melaksanakan kegiatan belajar mengajar, 10 orang atau $(28,60 \%)$ sering mengadakan persiapan, dan 2 orang atau $(5,70 \%)$ guru jarang membuat persiapan. Dengan rata-rata skor 4,60 berarti guru selalu membuat persiapan sebelum KBM.

\section{Proses Pembelajaran}

\section{Praktik di Bengkel}

Guru sering mendemontrasikan materi praktik kepada peserta didik dan selalu mengawasi peserta didik dalam kegiatan praktik dari awal sampai pelajaran berakhir. Sedangkan hasil penilaian oleh guru sendiri menunjukkan bahwa guru selalu mendemontrasikan materi praktik kepada peserta didik dan selalu mengawasi kegiatan praktik dari awal sampai berakhirnya kegiatan praktik.

\section{Teori di Kelas}

Tabel 2. Proses Pembelajaran Teori

\begin{tabular}{|l|c|c|}
\hline \multicolumn{1}{|c|}{ Komponen } & $\begin{array}{c}\text { Rerata } \\
\text { skor }\end{array}$ & Kriteria \\
\hline $\begin{array}{l}\text { Memulai dan mengakhir KBM } \\
\text { tepat waktu }\end{array}$ & 4,49 & Selalu \\
\hline $\begin{array}{l}\text { Pemahaman guru terhadap } \\
\text { materi yang diajarkan }\end{array}$ & 4,29 & $\begin{array}{c}\text { Sangat } \\
\text { Baik }\end{array}$ \\
\hline
\end{tabular}

Berdasarkan penilaian siswa persentase guru yang menyampaikan tujuan pembelajaran seperti gambar di bawah ini.

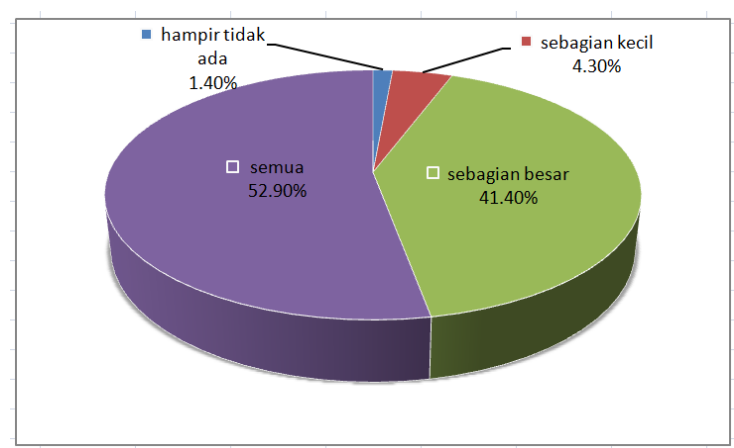

Gambar 18. Persentase Guru yang Menyampaikan Tujuan Pembelajaran Berdasarkan Penilaian Siswa

Berdasarkan data diperoleh 1 orang atau $(1,40 \%)$ memilih kategori hampir tidak ada, 3 orang atau $(4,30 \%)$ sebagian kecil guru,
29 orang atau $(41,40 \%)$ sebagian besar guru, dan 37 atau $(52,90 \%)$ menilai semua guru menyampaikan tujuan pembelajaran setiap pertemuan. Dengan rata-rata skor 4,46 termasuk dalam kategori sangat baik.

\section{Kerja sama dengan Institusi Lain}

1. Praktik Kerja Industri

Pelaksanaan kegiatan praktik industri berdasarkan penilaian siswa diperoleh rerata skor 4,41 hal ini menunjukkan pelaksanaan kegiatan praktik industri termasuk kategori sangat baik.

2. Penyaluran Lulusan

Intensitas siswa mendapatkan informasi berkaitan dengan lowongan kerja maupun penempatan kerja diperoleh rerata skor 4,07 termasuk kategori sangat baik dalam arti siswa selalu mendapatkan informasi mengenai lowongan kerja maupun penempatan kerja.

\section{Evaluasi Produk}

\section{Kompetensi Siswa}

Kompetensi siswa dalam hal ini ditinjau dari hasil Ujian Nasional dari tahun pertama mengikuti Ujian Nasional dapat dilihat pada Tabel 3, sedangkan nilai hasil Ujian Nasional dua tahun terakhir terlihat pada Tabel4 dan Tabel 5.

Tabel 3. Persentase Kelulusan SMK Kelas Jauh

\begin{tabular}{ccccc}
\hline & & Jumlah Siswa & Jumlah & \\
No & $\begin{array}{c}\text { Tahun } \\
\text { Kelus XII yang } \\
\text { mengikuti Ujian } \\
\text { Nasional }\end{array}$ & $\begin{array}{c}\text { Siswa } \\
\text { Tidak } \\
\text { Lulus }\end{array}$ & $\begin{array}{c}\text { Persentase } \\
\text { Kelulusan }\end{array}$ \\
\hline 1 & $2006 / 2007$ & 58 & - & $100 \%$ \\
2 & $2007 / 2008$ & 70 & - & $100 \%$ \\
3 & $2008 / 2009$ & 69 & 1 & $98,55 \%$
\end{tabular}

Pada tahun ajaran 2007/2008 tidak menerima siswa baru, sehingga pada tahun 2009/2010 tidak ada kelulusan.

$\begin{array}{lllll}5 & 2010 / 2011 & 64 & - & 100 \% \\ 6 & 2011 / 2012 & 98 & - & 100 \% \\ 7 & 2012 / 2013 & 70 & - & 100 \%\end{array}$


Berdasarkan Tabel 3 terlihat bahwa selama enam kali atau enam tahun mengikuti Ujian Nasional hanya 1 anak yang tidak berhasil. Hal ini menunjukkan bahwa kualitas SMK Kelas Jauh dapat bersaing dengan SMK pada umumnya.

Tabel 4. Nilai Ujian Nasional Tahun Pelajaran 2011/2012

\begin{tabular}{cccccc}
\hline Nilai & BIN & ING & MAT & PRO & JMLH \\
\hline Klasifikasi & A & A & A & A & A \\
Rata-rata & 7,88 & 7,74 & 8,65 & 8,17 & 32,44 \\
Terendah & 3,60 & 2,20 & 3,00 & 7,41 & 21,17 \\
Tertinggi & 9,40 & 9,80 & 10,00 & 9,17 & 36,85 \\
Std. Deviasi & 0,82 & 1,19 & 0,96 & 0,33 & 2,27 \\
\hline
\end{tabular}

Tabel 5. Nilai Ujian Nasional Tahun Pelajaran 2012/2013

\begin{tabular}{cccccc}
\hline Nilai & BIN & ING & MAT & PRO & JMLH \\
Klasifikasi & A & B & C & A & B \\
Rata-rata & 7,68 & 6,91 & 5,85 & 8,71 & 29,15 \\
Terendah & 3,40 & 3,80 & 2,00 & 7,88 & 19,84 \\
Tertinggi & 10,00 & 9,40 & 10,00 & 9,50 & 36,16 \\
Std. Deviasi & 1,14 & 1,15 & 1,97 & 0,28 & 3,73 \\
\hline
\end{tabular}

Berdasarkan Tabel 4 dan Tabel 5 maka klasifikasi nilai ujian nasional Tahun Pelajaran 2011/2012 dan 2012/2013 termasuk kategori sangat baik.

Berdasarkan penilaian guru jumlah siswa yang mendapat nilai minimal KKM diakhir pembelajaran sebelum diadakan program remedial diperoleh rerata skor 3,26 atau sebesar 41 s.d $60 \%$.

Sedangkan data kompetensi siswa berdasarkan prestasi bidang akademik maupun nonakademik sangat baik terlihat dari beberapa kejuaraan baik di tingkat kabupaten maupun propinsi telah diraih siswa SMK Kelas Jauh di MAN Karanganyar. Prestasi siswa dapat dilihat pada Tabel 6 .
Tabel 6. Prestasi Siswa

No Tahun $\begin{array}{ll}\text { Nama } & \text { Kejuaraan } \\ \text { Siswa }\end{array}$

1. 2007 Yulianto Juara II Lomba Keterampilan Siswa SMK Teknik Mesin Perkakas Se-Kabupaten Karanganyar

2. 2008 Heru Juara II Lomba Keterampilan Siswa SMK Teknik Mesin Perkakas Se-Kabupaten Karanganyar

3. 2008 Tangguh Juara I Lomba Mata Pelajaran Subari SMK Matematika Teknik SeKabupaten Karanganyar

4. 2008 Andi Juara II Lomba Mata Pelajaran Setiawan SMK Matematika Teknik SeKabupaten Karanganyar

5. 2008 Miftah Juara I Panjat Tebing Lead Syafii Pelajar Putera SPTP -FPTI SeKabupaten Karanganyar

6. 2012 Sadikan Juara II Lomba Tinju Pelajar Tingkat Propinsi

7. 2012 Abdul Juara III Lomba Kompetensi Rokhip Siswa Bidang Production Machine SMK Se-Kabupaten Karanganyar

\section{Keterserapan Lulusan}

Kemudahan lulusan mendapatkan pekerjaan diperoleh rerata skor 3,63 artinya lulusan SMK Kelas Jauh di MAN Karanganyar mudah mendapatkan pekerjaan. Sedangkan kesiapan siswa setelah belajar di SMK Kelas jauh untuk menghadapi dunia kerja diperoleh rerata skor 4,41 artinya peserta didik sangat siap untuk memasuki dunia kerja.

\section{Kepuasan/tanggapan masyarakat}

Kepuasan dan tanggapan masyarakat terhadap lulusan SMK Kelas Jauh terlihat pada Tabel 7 di bawah ini. 
Tabel 7. Kepuasan dan Tanggapan Masyarakat terhadap Lulusan

\begin{tabular}{ccc}
\hline Komponen & $\begin{array}{c}\text { Rerata } \\
\text { skor }\end{array}$ & Kriteria \\
\hline $\begin{array}{c}\text { Kepuasan masyarakat } \\
\text { terhadap lulusan }\end{array}$ & 4,03 & $\begin{array}{c}\text { Sangat } \\
\text { puas }\end{array}$ \\
$\begin{array}{c}\text { Tanggapan/pengakuan } \\
\text { masyarakat terhadap lulusan }\end{array}$ & 4,09 & $\begin{array}{c}\text { Sangat } \\
\text { baik }\end{array}$ \\
\hline
\end{tabular}

Berdasarkan tabel tersebut menunjukkan bahwa masyarakat sangat puas terhadap lulusan. Tanggapan/pengakuan terhadap lulusan juga sangat baik.

\section{Pembahasan Hasil Evaluasi Context}

Evaluasi context meliputi: kepedulian dan harapan masyarakat, relevansi program, serta regulasi dan kebijakan pemerintah. Hasil rata-rata evaluasi keseluruhan komponen context siswa sebesar 23,73 termasuk cukup relevan. Sedangkan hasil rata-rata evaluasi keseluruhan komponen context guru sebesar 41,14 termasuk kategori relevan. Hal ini berarti adanya relevansi terhadap konteks penyelenggaraan SMK Kelas Jauh di MAN Karanganyar. Penyelenggaraan SMK Kelas Jauh di MAN Karanganyar sesuai dengan potensi lokal dimana Kabupaten Karanganyar merupakan daerah industri. Terdapat industri logam misalnya P.T. SASS, industri tekstil (P.T. Sritex), pabrik jamu (P.T. Air Mancur), pabrik gula (P.G. Tasikmadu) serta beberapa industri pemesinan tingkat rumah tangga yang menyuplai beberapa bahan untuk industri besar tersebut.

Kepedulian Pemda dalam kategori baik dengan kata lain keberadaan SMK Kelas Jauh didukung oleh Pemda. Kepedulian Pemda ditunjukkan dengan mengeluarkan ijin untuk penyelenggaraan SMK Kelas Jauh, ajangsana Kepala Daerah dalam hal ini bupati serta adanya fasilitasi bantuan dari Pemda. Dukungan dari pemerintah juga ditunjukkan melalui pendanaan dari awal sekolah berdiri hingga berjalan.

Kepedulian orang tua siswa juga dalam kategori baik, ini artinya bahwa orang tua siswa mendukung anaknya bersekolah di SMK Kelas Jauh. Hal ini dikarenakan keberadaan SMK Kelas Jauh sangat sesuai dengan harapan dan kebutuhan masyarakat. Berdasarkan evaluasi konteks bahwa program yang dise- lenggarakan SMK Kelas Jauh juga sesuai harapan dan kebutuhan siswa. Siswa sangat yakin bahwa program yang diselenggarakan SMK Kelas Jauh sangat bermanfaat bagi siswa sendiri.

Melalui analisis konteks bahwa program SMK Kelas Jauh sesuai dengan kondisi ekonomi masyarakat sekitar. Potensi yang dimiliki sekolah pun mendukung diselenggarakannya program SMK Kelas Jauh. Kesesuaian program SMK Kelas Jauh dengan potensi siswa sangat sesuai.

Animo masyarakat tergolong cukup tinggi untuk menyekolahkan anaknya ke SMK Kelas Jauh di MAN Karanganyar meskipun hal ini terkait dengan kuota yang ditetapkan dari SMK induk. Masyarakat melihat di SMK Kelas Jauh memiliki nilai plus yakni berkaitan dengan nilai-nilai keagamaan. Masyarakat menginginkan selain anaknya mempunyai keterampilan yang memadai sebagai bekal hidup masa depan juga mendambakan anaknya mempunyai akhlaq mulia dalam kehidupannya. Pembentukan kebiasaan yang Islami terlihat dari pembiasaan tilawah (mengaji AlQur'an) tiap pagi hari, sholat dhuhur wajib dilakukan secara berjamaah, kegiatan pesantren kilat, maupun kemah dakwah setiap Bulan Romadhon.

Keberadaan SMK Kelas Jauh di MAN Karanganyar terletak pada daerah yang sangat strategis. Lokasi sekolah yang sangat strategis merupakan jalur lintas selatan Kabupaten Karanganyar sehingga relatif mudah dijangkau.

Dari sisi regulasi dan kebijakan pemerintah, penyelenggaraan SMK Kelas Jauh di MAN Karanganyar sangat didukung oleh aturan atau kebijakan yang ada mulai dari tingkat pusat, provinsi, maupun kabupaten. Dari tingkat pusat bahwa SMK Kelas Jauh merupakan program pemerintah mulai tahun 2003, sehingga keberadaannya sangat didukung dalam rangka ikut mengatasi keterbatasan akses pendidikan serta program pemerintah yang melakukan perubahan besar terhadap perbandingan SMK dan SMA yaitu 70:30. Di tingkat provinsi ditegaskan bahwa Provinsi Jawa Tengah telah mendeklarasikan sebagai Provinsi Vokasi. Begitu pula Kabupaten Karanganyar telah mendeklarasikan sebagai Kabupaten Vokasi. Hal ini dikarenakan di Karanganyar jumlah sekolah SMK lebih banyak dari pada jumlah SMA. Kebijakankebijakan tersebut tentunya juga mendukung 
keberadaan SMK Kelas Jauh di MAN Karanganyar yang merupakan juga bagian dari sekolah kejuruan.

\section{Pembahasan Hasil Evaluasi Input}

Komponen input meliputi karakteristik guru, karakteristik siswa, kurikulum, serta karakteristik sarana dan prasarana. Evaluasi input menurut siswa maupun input menurut guru secara keseluruhan termasuk dalam kategori baik.

Hasil penelitian menunjukkan bahwa karakteristik guru ditinjau dari motivasi kerja termasuk kurang. Hal ini terlihat dari guru bersedia melaksanakan tugas hanya jika diberi penghargaan kepala sekolah. Beberapa guru bekerja dengan baik hanya untuk mendapatkan pengakuan dari kepala sekolah. Struktur organisasi SMK Kelas Jauh yang masih lebur dengan MAN Karanganyar bisa jadi menjadi salah satu penyebabnya, sehingga tugas di SMK Kelas Jauh kurang fokus dan terkesan tumpang tindih serta adanya penumpukan tugas dan wewenang oleh beberapa pengelola.

Persentase guru yang mengembangkan media pembelajaran sendiri termasuk kategori baik. Hal ini juga didukung persentase guru yang selalu berusaha meningkatkan kompetensi diri dengan mengikuti pelatihan-pelatihan termasuk kategori sangat baik.

Kuantitas atau jumlah guru yang tersedia juga mencukupi untuk melaksanakan pembelajaran. Guru terdiri dari guru normatif dan adaptif dipenuhi dari Madrasah Aliyah sedangkan untuk guru produktif sebagiannya dari SMK induk. Namun guru produktif hasil out sourcing dari SMKN 2 Karanganyar hanya sebatas tugas mengajar, tidak dimungkinkan diberi beban sebagai pengelola karena tugas pokoknya di SMK induk dengan kata lain di SMK Kelas Jauh hanya sebatas tambahan saja.

Kualifikasi guru SMK Kelas Jauh di MAN Karanganyar sangat sesuai antara mata pelajaran yang diampu dengan latar pendidikan guru. Hal ini juga didukung bahwa pelatihan-pelatihan yang telah diikuti guru sesuai dengan latar pendidikannya sehingga dapat menambah kemampuan guru dalam melaksanakan pembelajaran. Dari 35 guru terdapat 6 guru $(17,14 \%)$ guru berpendidikan S2 dan 29 guru $(82,86 \%)$ telah berpendidikan S1. Selain itu $97 \%$ guru yang bekerja di SMK Kelas Jauh telah mempunyai pengalaman kerja di atas tiga tahun. Sebagian besar guru $(84,60 \%)$ guru juga telah mengikuti pelatihan yang sesuai dengan latar pendidikan.

Input siswa berdasarkan Nilai Evaluasi Murni dari SMP termasuk dalam kategori baik. Karakteristik siswa diantaranya adalah motivasi belajar. Indikator yang pertama motivasi belajar yaitu kedisiplinan siswa masuk kelas tepat waktu. Hasil penelitian menunjukkan bahwa sebagian besar siswa selalu masuk kelas tepat waktu. Indikator yang kedua yaitu adanya niat atau kesadaran dalam belajar. Hasil kuesioner menunjukkan bahwa sebagian siswa menyatakan bahwa belajar di SMK Kelas Jauh merupakan pilihan pertama. Siswa yakin bahwa program yang diselenggarakan di SMK Kelas Jauh sangat bermanfaat bagi dirinya. Untuk meningkatkan motivasi belajar siswa disetiap akhir semester diberikan beasiswa kepada siswa yang juara paralel sekolah dengan ketentuan sebagai berikut: 1) juara 1 mendapatkan hadiah bebas Sumbangan Operasional Pendidikan (SOP) selama 6 bulan; 2) Juara 2 mendapatkan hadiah bebas SOP selama 4 bulan; 3) juara 3 mendapatkan hadiah bebas SOP selama 2 bulan

SMK Kelas Jauh di MAN Karanganyar bernuansa ke-Islaman. Namun sesuai hasil penelitian bahwa latar belakang pendidikan siswa sebanyak $(91,40 \%)$ adalah dari Sekolah Menengah Pertama (SMP) bukan dari Madrasah Tsanawiyah (MTs). Hal ini menunjukkan bahwa SMK Kelas Jauh di MAN Karanganyar diminati oleh siswa dari sekolah umum.

Sosio economic status atau status ekonomi sosial orang tua siswa ditinjau dari penghasilan, tingkat pendidikan, dan pekerjaan orang tua. Hasil penelitian ditinjau dari penghasilan orang tua siswa menunjukkan bahwa sebagian besar orang tua tergolong pada lapisan ekonomi menengah ke bawah. Tingkat pendidikan orang tua sebagian besar yaitu Sekolah Dasar (SD). Dengan demikian tingkat pendidikan orang tua termasuk kategori rendah. Sedangkan pekerjaan orang tua siswa sebagian besar adalah buruh tani maupun buruh bangunan, wiraswasta, karyawan pabrik, dan juga pedagang.

Kurikulum yang digunakan SMK Kelas Jauh di MAN Karanganyar sama dengan kurikulum SMK induk yaitu SMKN 2 Karanganyar. Dengan cirri khas yang Islami maka SMK Kelas Jauh di MAN Karanganyar menambahkan kompetensi Bahasa Arab dan 
Keterampilan Las di mana kompetensi ini tidak ada di SMK induk. Ciri khas yang lain yaitu adanya pembiasaan tilawah (membaca Al-qur'an) untuk mengawali pelajaran tiap pagi hari. Menurut hasil penelitian bahwa kurikulum yang digunakan sangat sesuai dengan kebutuhan masyarakat.

Dokumen kurikulum yang dimiliki SMK Kelas Jauh di MAN Karanganyar termasuk lengkap. Guru sering terlibat dalam penyusunan kurikulum namun keterlibatan guru perlu ditingkatkan. Silabus yang dibuat sudah sangat lengkap untuk pedoman pembuatan rencana pelaksanaan pembelajaran.

Karakteristik sarana dan prasarana ditinjau dari gedung dan ruang pembelajaran rata-rata cukup memadai. Namun sarana bermain/olah raga perlu diperbaiki. Sebaiknya diusahakan semua kegiatan olah raga diselenggarakan di lingkungan sekolah. Sarana bahan dan alat praktik termasuk lengkap.. Sarana yang perlu ditingkatkan adalah ruang perpustakaan dan ketersediaan buku referensi untuk belajar.

\section{Pembahasan Hasil Evaluasi Process}

Program keahlian yang diselenggarakan oleh SMK Kelas Jauh di MAN Karanganyar sesuai yang ada di SMK induk yaitu Teknik Pemesinan. Kompetensi Keahlian Teknik Pemesinan di SMKN 2 Karanganyar terakreditasi A (amat baik). Peserta didik SMK Kelas Jauh tercatat sebagai siswa SMKN 2 Karanganyar. Nomor Induk Sekolah dan ijazah yang mengeluarkan adalah SMKN 2 Karanganyar.

Evaluasi process ditinjau dari persiapan pembelajaran yaitu persiapan sebelum KBM dan pembuatan RPP. Guru juga selalu membuat RPP diawal semester. RPP merupakan Rencana Pelaksanaan Pembelajaran agar pembelajaran yang disampaikan terarah dan dapat terukur.

Proses pelaksanaan pemelajaran teori dan praktik (selain praktik CNC) dilaksanakan di SMK Kelas Jauh di MAN Karanganyar. Pada proses pembelajaran praktik di bengkel guru selalu mendemontrasikan materi praktik kepada siswa sebelum pelajaran dimulai. Saat pelajaran praktik guru selalu mengawasi siswa dari awal pelajaran sampai pelajaran berakhir. Perlu menjadi catatan yaitu beberapa pelajaran seperti olah raga dan praktik $\mathrm{CNC}$ masih dilakukan di luar kampus SMK Kelas
Jauh sehingga memungkinkan menurunnya ketertiban siswa.

Pada proses pembelajaran teori di kelas terlihat proses KBM berjalan dengan baik. Guru selalu memulai dan mengakhiri KBM tepat waktu. Pemahaman guru terhadap materi yang diajarkan termasuk sangat baik. Sedangkan siswa antusias dalam belajar. Apabila ada tugas dari guru maka siswa berusaha menyelesaikan tugas dengan sebaik-baiknya. Guru menggunakan berbagai strategi dalam KBM untuk menghindari kejenuhan siswa. Guru juga selalu mengkoreksi tugas pekerjaan siswa dan mengembalikannya kepada siswa. Di setiap awal pelajaran sebagian besar guru menyampaikan tujuan pembelajaran sehingga siswa mengetahui manfaat apa yang akan dipelajari. Suasana sekolah juga dirasakan nyaman untuk kegiatan belajar siswa.

Komponen proses penilaian hasil pembelajaran guru menilai siswa dari aspek sikap, pengetahuan dan keterampilan siswa. Diakhir pembelajaran guru selalu mengadakan program tindak lanjut dengan melaksanakan program remedial bagi siswa yang belum memenuhi Kriteria Ketuntasan Minimal (KKM).

Kerja sama dengan institusi lain yang dilakukan melalui kegiatan Praktik Kerja Industri yang dilakukan siswa dan penyaluran lulusan. Kegiatan Praktik Kerja Industri terlaksana dengan sangat baik. Hal ini terbukti dengan bertambahnya DU/DI setiap tahunnya. Siswa sangat sering mendapatkan informasi berkaitan dengan lowongan kerja maupun penempatan kerja. Sedangkan kerja sama dengan SMK induk meliputi proses penerimaan siswa baru, masa orientasi siswa, dan uji kompetensi siswa.

Secara keseluruhan pada evaluasi proses penyelenggaraan SMK Kelas Jauh di MAN Karanganyar baik dinilai dari siswa maupun guru termasuk dalam kategori baik.

\section{Pembahasan Hasil Evaluasi Product}

Evaluasi produk siswa ditinjau dari hasil Ujian Nasional tiga tahun terakhir termasuk sangat baik dengan klasifikasi nilai $\mathrm{A}$. Tingkat kelulusan tiga tahun terakhir mencapai $100 \%$. Beberapa prestasi bidang akademik maupun nonakademik baik tingkat kabupaten maupun provinsi pernah diraih siswa SMK Kelas Jauh. Namun apabila dilihat dari ketercapaian jumlah siswa yang mendapat nilai minimal KKM di akhir pembelajaran 
sebelum diadakan program remedial termasuk kategori masih rendah. Menurut pengelola SMK Kelas Jauh di MAN Karanganyar hal ini mungkin terjadi karena beberapa siswa yang sekolah di SMK Kelas Jauh merupakan siswa yang tidak tertampung di SMK induk. Penunjang pembelajaran di antaranya perpustakaan yang belum tersedia dengan lengkap juga merupakan sebab rendahnya nilai keseharian siswa.

Keterserapan lulusan tergolong baik. Hal ini tercermin dari mudahnya lulusan mendapatkan pekerjaan. Data penelusuran tamatan tahun 2012 terdapat 77 atau $(82,79 \%)$ dari 93 lulusan bekerja di berbagai perusahaan, 9 atau $(9,68 \%)$ lulusan melanjutkan studi, 6 atau $(6,45 \%)$ lulusan langsung mengikuti magang di Jepang, dan 1 atau $(1,08 \%)$ lulusan tidak diketahui pekerjaannya. Hasil penelitian juga menunjukkan bahwa siswa sangat siap untuk memasuki dunia kerja.

Keterampilan yang diberikan SMK Kelas Jauh di MAN Karanganyar juga termasuk baik. Siswa merasa puas dengan keterampilan yang didapatkan selama belajar di SMK Kelas Jauh. Tanggapan masyarakat juga sangat baik terhadap kualitas lulusan. Sehingga dapat disimpulkan bahwa evaluasi produk secara keseluruhan produk yang dihasilkan oleh SMK Kelas Jauh di MAN Karanganyar termasuk cukup baik tidak kalah dengan alumni dari SMK yang lain.

\section{SIMPULAN DAN SARAN}

\section{Simpulan}

Berdasarkanhasil penelitian, dan pembahasan maka pelaksanaan program SMK Kelas Jauh di MAN Karanganyar dapat disimpulkan sebagai berikut:

1. Berdasarkan aspek context terdiri dari tiga variabel sebagai berikut. (1) Kepedulian dan harapan masyarakat termasuk dalam kategori baik; (2) Relevansi program penyelenggaraan SMK Kelas Jauh termasuk relevan dengan kebutuhan masyarakat dan potensi lokal; (3) Ditinjau dari aspek regulasi dan kebijakan pemerintah, baik pemerintah pusat maupun daerah sangat mendukung penyelenggaraan SMK Kelas Jauh di MAN Karanganyar.

2. Berdasarkan aspek input ditinjau dari karakteristik guru; motivasi kerja masih kurang, kuantitas guru mencukupi, kua- lifikasi dan kompetensi guru sangat sesuai yang diharapkan. Ditinjau dari karakteristik siswa; input siwa berdasarkan Nilai Evaluasi Murni dari sekolah sebelumnya termasuk baik, motivasi dan kesadaran untuk belajar cukup, sebanyak $44 \%$ siswa setelah lulus ingin bekerja ikut orang, $43 \%$ ingin bekerja mandiri dan selebihnya ingin melanjutkan studi maupun kursus. Status sosial ekonomi orang tua siswa termasuk menengah ke bawah. Ditinjau dari kurikulum yang digunakan sesuai dengan kebutuhan masyarakat dan dokumen kurikulum termasuk lengkap. Ditinjau dari sarana dan prasarana baik itu ruang pembelajaran, maupun alat dan bahan praktik sudah memadai. Namun perlu ditingkatkan sarana olah raga dan perpustakaan.

3. Berdasarkan aspek process secara umum proses penyelenggaraan SMK Kelas Jauh di MAN Karanganyar termasuk baik. Ditinjau dari persiapan pembelajaran bahwa guru telah membuat persiapan sebelum mengadakan KBM. Proses kegiatan belajar praktik di bengkel sangat baik dengan adanya pemberian contoh oleh guru dan pengawasan dalam kegiatan praktik. Proses pembelajaran teori termasuk kategori baik. Guru selalu membuat persiapan sebelum mengajar. Guru memulai dan mengakhiri KBM tepat waktu. Guru menggunakan berbagai teknik dalam pembelajaran dan siswa antusias dalam belajar. Kerja sama dengan institusi lain dalam kegiatan Prakerin dan penyaluran lulusan terlaksana dengan baik.

4. Berdasarkan aspek product ditinjau dari nilai ujian nasional tiga tahun terkahir termasuk sangat baik dengan rata-rata klasifikasi nilai A (amat baik) serta tingkat kelulusannya mencapai $100 \%$. Prestasi siswa dalam kategori baik dengan diraihnya beberapa kejuaraan di tingkat Kabupaten maupun Provinsi. Keterserapan lulusan termasuk baik. Data penelusuran tamatan tahun 2012 terdapat $82,79 \%$ lulusan bekerja di berbagai perusahaan dan 9,68\% lulusan melanjutkan studi. Tanggapan masyarakat terhadap lulusan dengan rerata skor $(4,09)$ termasuk sangat baik.

\section{Saran}

Saran-saran yang dapat diberikan sebagai bahan masukan untuk perbaikan sekolah 
adalah sebagai berikut: 1) untuk meningkatkan rasa handarbeni bagi semua guru dan karyawan perlu diadakan kegiatan-kegiatan semacam training motivasi; 2) hendaknya sekolah melengkapi sarana olah raga dan menambah koleksi buku perpustakaan; 3) karakteristik sekolah dengan pembiasaan-pembiasaan Islami perlu dipertahankan; 4) dengan beberapa fasilitas yang ada SMK Kelas Jauh di MANKaranganyar dimungkinkan untuk membuka jurusan yang lain seperti pengelasan, otomotif, mebelair, ataupun busana butik.

\section{DAFTAR PUSTAKA}

Ajit Kumar, N. S. (2011). Criteria for evaluating the quality of a question paper [Versi Cetak]. Journal of technical education and training, 3, 59-64.

AS Hornby. (1986). KamusOxford Advanced Learner's Dictionary of Current English. New York:Oxford University Press.

Basuki Wibawa. (2005). Pendidikan teknologi kejuruan: manajemen dan implementasinya di era otonomi. Surabaya: Kertajaya Duta Media.

Doni M, dkk. (2010). Inovasi dalam sistem pendidikan potret praktik tata kelola pendidikan menengah kejuruan. Jakarta: Direktorat Penelitian dan Pengembangan Komisi Pemberantasan Korupsi.

http://www.cglrc.cgiar.org/icraf/toolkit/The_C IPP_evaluation_model.htm diunduh, 16 Oktober 2012

http://www.suaramerdeka.com/v1/index.php/r ead/cetak/2008/04/08/8061/22-SMKDiusulkan-Jadi-SBI diunduh tanggal 11 Januari 2012

Karanganyar Menuju Kota Vokasi. (03 Mei 2013). Solopos, p. 9.

Nolker H, Eberhad S. (1983). Pendidikan kejuruan: pengajaran, kurikulum, perencanaan. (Terjemahan Agus Setiadi) Jakarta: PT. Gramedia.

Proverty Team. (2010). Laporan ketenagakerjaan di Indonesia menuju terciptanya pekerjaan yang lebih baik dan jaminan perlindungan bagi para pekerja. Jakarta: Kantor Bank Dunia Jakarta.

SentotWijanarka. (25 Juli 2009). Peranan TIK dalam pengembangan materi ajar dan strategipembelajaranmata diklat memprogram mesin CNCdiSMK. Makalah disajikan dalam Seminar Nasional Penerapan ICT dalam Pembelajaran, PHK-I UNY.

Slamet PH. (2005). Pengembangan kapasitas untuk mendukung desentralisasi pendidikan kejuruan. Yogyakarta: Naskah Pidato, tidak diterbitkan, Pengukuhan Guru Besar dalam Bidang Ilmu Pendidikan Teknologi dan Kejuruan pada Fakultas Teknik UNY.

Soenarto. (2003). Kilas balik dan masa depan pendidikan dan pelatihan kejuruan (suatu evaluasi pendidikan dan pelatihan kejuruan di Indonesia). Yogyakarta: Naskah Pidato, tidak diterbitkan, Pengukuhan Guru Besar dalam Bidang Ilmu Pendidikan Teknologi Kejuruan pada Fakultas Teknik UNY.

Stufflebeam, L.D. \& Shinkfield, A.J. (1985). Systimatic evaluation; a self instructional guide to theory and practice. Kluwer-Nijholf Publishing.

Sugiyono. (2003). Profesionalisme manajemen pendidikan kejuruan di Indonesia. Yogyakarta: Naskah Pidato, tidak diterbitkan, Pengukuhan Guru Besar dalam Bidang Ilmu Manajemen Pendidikan Teknologi Kejuruan pada Fakultas Teknik UNY.

Thomas Sukardi. (2012). Peranan bimbingan kejuruan terhadap pembentukan karakter kerja pada pembelajaran teknik pemesinan. Yogyakarta: Naskah Pidato, tidak diterbitkan, Pengukuhan Guru Besar dalam Pembelajaran Teknik Pemesinan Pada Fakultas Teknik UNY.

Tyler, R.W. (1949). Basic principles of curriculum and instruction. Chicago: The University of Chicago Press.

Udin Syaefudin. (2010). Inovasi pendidikan. Bandung: Alfabeta.

Wardiman Djojonegoro. (1998). Pengembangan sumberdaya manusia melalui sekolah menengah kejuruan (SMK). Jakarta: P. T. Jayakarta Agung Offset.

Worthen, B. R. \& Sanders, J. R. (1973). Educational evaluation: theory and practice. Belmort, California: Wadswort $\mathrm{Pu}-$ blishing Inc. 